\title{
MARKETING TECHNIQUES FOR THE COMMUNITY-BASED ENTERPRISE
}

\author{
CARL E. BLocK*
}

\section{INTRODUCTION}

Prior to making any attempt at addressing the theme of this paper suggested by the title, it is imperative to establish a conceptual base with respect to the fundamental nature of community-based enterprises. This is particularly important because of the lack of a consensus among interested parties concerning such basic questions as "What is a community development corporation?" and "How should its objectives ordinarily be framed?"

To establish this point of departure, two steps are taken. First, a set of assumptions is offered to lay the major portion of the conceptual base referred to above. And no doubt there may be considerable disagreement on these issues. Nevertheless, this is a necessary first step. Then, attention is given to more specific instances evidencing attempts by community development corporations (CDC) to carry out their perceived responsibility. Following these introductory sections, the remainder of the paper will be devoted to a discussion of the marketing aspects of the community-based enterprise's operation. In this latter part, specific attention will first be given to the marketing considerations which must be examined in the servicing of the local constituency in light of its particular characteristics and modes of life. This orientation toward the immediate neighborhood will be followed by an emphasis on the advantages of and problems associated with trying to reach out to serve a broader market.

The initial assumptions regarding community development corporations are as follows: (a) the private profit system has not sufficiently nurtured the growth and development of private enterprises which are capable of meeting the needs of lowincome communities for goods and services; (b) there is considerable interest on the part of residents of economically depressed areas to cooperate in a community controlled venture in an attempt to free themselves from public dependency; (c) the community development corporation, offering neighborhood participation, is a viable type of organization for facilitating the drive for independence; (d) the CDC is a locally-based organization that conducts revenue-generating business with the primary purpose of fostering economic development of the immediate area; (e) the CDC can provide many essential goods and services for local residents while still contributing to the development of a desirable economic base in the depressed area it is serving; (f) since the primary objective of the CDC is to contribute to

- Associate Professor of Marketing, School of Business and Public Administration, University of Missouri-Columbia. 
economic development, trade-offs will occasionally be necessary between providing for the immediate social needs of the residents and economic growth; in such cases the latter will be favored; (g) the skill potential of the poor, that is, their innate capacity to learn, is sufficient that such persons can acquire the necessary know-how to participate actively in community-based enterprises; $(h)$ there is sufficient interest on the part of society generally to commit substantial catalytic resources for economic development of depressed areas and this support is a product of an interest that can be relied upon over an extended period of time; (i) it is not the purpose of the community development corporation to foster a particular level of racial integration or separatism; and ( $j$ ) the plight of most depressed areas is so great, that no one organization, agency, or legislative act can be expected to resolve all economic problems; at best, progress will be made in phases with each new effort being built upon the experiences of earlier endeavors.

\section{CDC EXPERIENCE}

Community development corporation business action to date can be categorized as either essentially catalytic-directed toward encouraging the formation and/or growth of private business-or more typically, as participatory-taking form through direct organization involvement in revenue-generating business. No matter which orientation has been the focal point of a particular CDC, the immediate neighborhood has been the market of greatest interest.

\section{A. Catalytic Action}

Much has been said about the catalytic effects of the community development corporation on the development and revitalization of private minority enterprises. So far none of the CDC's have acted in a strictly catalytic manner, although a number proclaimed this to be their major function. The catalytic action that has been taken by CDC's can be classified as direct, or overt, action and indirect, or secondary, action.

Probably the most effective organization in direct catalytic action has been the Inner City Business Improvement Forum. ICBIF, an all-black financial organization through which the Detroit power structure is channeling its assistance, had utilized almost $\$ 1,000,000$ of its funds for loans or investment in eighty-six black businesses by early 1970. In addition, ICBIF had participated with Detroit banks and the Small Business Administration in loan packages worth $\$ 3,700,000$. While ICBIF cannot claim to have solved the capital problem for minority enterprises, it has engendered a growing confidence of Detroit banks in the black business community. The six Detroit banks with SBA guarantees increased minority business loans from $\$ 703,000$ in 1968 to $\$ 5,600,000$ in 1969 . In addition to financing private

\footnotetext{
${ }^{1}$ As an example, Hough Development Corporation's strategy of business was to ". . act essentially as a catalyst, using its funds as leverage rather than as direct investment whenever possible." The Hough Development Corporation, Harvard Business School Case, 1969, p. 7. (xeroxed).
} 
black businesses, the ICBIF has made other direct catalytic efforts. Several campaigns have been organized by ICBIF and the Economic Development Corporation to bring potential black suppliers together with purchasing executives of Detroit corporations. Also, the ICBIF operates a computerized accounting service that furnishes free financial services for budding minority entrepreneurs. ICBIF does have direct interest and control in several projects. It is worth noting that ICBIF, while it is an all-black corporation, has not established as a goal community ownership or control. ${ }^{2}$

Another example of direct catalytic action is the Progress Plaza shopping center developed in I967 by Zion Investment Associates, Inc., of Philadelphia. ${ }^{3}$ Of the sixteen store spaces in the center, ten were available to operations with poor credit ratings. ${ }^{4}$ In addition, Zion was able to require that outside-owned businesses employ only community residents for all positions. Zion has received funding to assist in establishing similar ghetto shopping centers in other cities. Other CDC's, such as that in Cleveland's Hough area, are planning their own shopping centers, while still other community-based organizations, like Watts Labor Community Action Committee, are involved in providing community services such as vocational training; although this latter example is more appropriately classified as indirect action. ${ }^{\mathbf{5}}$

Much more difficult to perceive and measure are the effects of indirect catalytic action by CDC's. Generally there appear to be four categories of effects:

-development of business "infrastructure"

-creation of new markets

-community involvement

-momentum

Development of business infrastructure includes providing for manufacturing and office space, the training and motivation of potential minority entrepreneurs, development of desirable work habits among ghetto residents, and the establishment of lines of communication. Also important to infrastructure is the development of a minority equity market. Logically, the manufacturing operations started by CDC's will create a new demand for materials and services, which can potentially be supplied by the individual entrepreneur. Perhaps equally important is the potential creation of demand for goods and services complementing those produced by the CDC enterprise. Finally, it is obvious that community involvement and momentum are vital to the goals of minority economic development.

It can be reasoned that the major impediment to the accomplishment of direct catalytic action by CDC's in most instances is direct community ownership or control of the corporation. This goal is in conflict with the goal of the individual entre-

\footnotetext{
${ }^{3}$ Scott, Report from Detroit, ForTunE, Feb. I970, at 7I-72.

${ }^{8}$ Note, Community Development Corporations: Operations and Financing, 83 HaRv. L. REv. 1558, I562-67 (1970).

4All ten were leased by minority entrepreneurs, eight of whom were not in business prior to the shopping center development.

${ }^{8}$ Ackerson, supra note 3, at 1577 .
} 
preneur to run his business to maximize personal profit; however, it may be improper to categorize the entrepreneur of the depressed area according to classic entrepreneurial definitions. Another potential impediment is that the CDC may react to the temptation to achieve short-run success and proceed to marshal its limited talent and money into one unit.

\section{B. Participatory Action: Direct Operation of Businesses}

Although CDC's have acted as a catalyst in fostering the growth of private business in depressed areas, their primary mode of operation is that of conducting revenue-generating business as a means of producing substantial economic and social progress in their immediate environment. While CDC direct involvement has covered a variety of business ventures, all of the CDC's appear to have selected their businesses on the basis of at least one of two selection criteria. The operations are either labor-intense or they fill a pressing need for merchandising and service establishments which will broaden the patronage opportunities of the neighborhood residents. To a large exent, businesses meeting these criteria were plentiful in the area at one time, but for one reason or another, were no longer servicing the local community.

Such business selection on the part of CDC's gives what appears to be visible evidence of progress to both the impatient ghetto populace and program sponsorsevidence which in each case may be a prerequisite to continued support. In addition, business ventures selected on the basis of the two identified criteria foster immediate social benefits, such as reduced unemployment and the lessening of consumer exploitation, while the slower process of developing economic resources takes place.

Several CDC's have started with a venture intended not to return a significant profit, but rather to provide for certain pressing social needs. Zion Investment Associates of Philadelphia, one of the most successful CDC's, started in 1964 with this approach by building a housing project called Zion Garden Apartments. Since this initial project was completed, Zion has become involved in the aerospace and garment industries and has developed a local shopping center. ${ }^{6}$ Action Industries, Inc., a CDC in Venice, California, has been operating a number of small merchandising and service establishments with rather limited success. ${ }^{7}$ The Hough Development Corporation, a Cleveland CDC, has followed a similar strategy of business involvement. For instance, in 1969 the Hough CDC had the following businesses at various stages of consideration: a supermarket, dry cleaner, automotive center, donut shop, home maintenance service, taxi service and credit union. ${ }^{8}$

By contrast, there are few examples of successful on-going manufacturing facilities or wholesale distributorships operated by CDC's in depressed areas, even though these forms of business represent a more viable means of bringing wealth

\footnotetext{
${ }^{6} I d$. at $1564-65$.

T. Cross, Black Capitalism: Strategy for Business in the Ghetto 227 (1969).

8 The Hough Development Corporation, supra note 1 , at 226-28.
} 
into the local community since they would serve a broader market beyond the economy of the neighborhood. To a large extent CDC's have established business enterprises which offer an opportunity to maximize "social profits" with relatively little attention given to maximizing long-run "economic profits" through gaining control of capital.

II

\section{Market Oruentation}

It is apparent that CDC's at best have followed a traditional orientation to business management where emphasis is placed on developing and financing the physical plant and production facilities. This is in sharp contrast to most progressive firms today which are market-oriented organizations emphasizing such activities as marketing research, promotion, and dealer-customer relations as central, not peripheral, aspects of their management. ${ }^{9}$ Consequently, to be competitive in at least some of the markets that appear most promising for CDC cultivation, a very basic change is necessary. The CDC must broaden its perspectives so that substantial management attention is given to such activities as marketing, research, and promotion. Any meaningful discussion concerning the development of logically sound and operationally feasible marketing strategies for CDC use must include suggestions dealing with servicing the consumer of the immediate neighborhood, but not neglect the broader market beyond this depressed environment. A part of the conception of a broader market for the CDC involves reaching out to serve various governmental divisions as well as private businesses.

\section{A. The Consumer Market}

Research evidence shows that the typical consumer goods marketer today is increasingly facing a younger, better-educated, more perceptive and more affuent market than ever before. During the next ro years, median family income will probably increase by more than fifty per cent to at least $\$ 15,000$ per year. At the end of World War II, less than ten million people had at least some college education. At the close of 1969 , there were twenty million with this level of attainment. And by I980, there will be close to thirty-three million with at least some college training. In $x 965$, there were $4 \mathrm{I} .5$ million families with household heads under thirtyfive years old. Now there are nearly forty-five million. As a result of such changes firms are being forced to modify the assumptions upon which their marketing strategies are based. ${ }^{10}$

Old fears regarding the consequences of breaking with tradition in such areas as store patronage, brand selection, and credit arrangement have all but been abandoned by consumers. Therefore, marketers have had to sharpen their skills in the

\footnotetext{
'L. Preston, Markets and Marketing: An Orientation 79-80 (I970).

${ }^{20}$ Selling to the Hottest Market Ever, Bus. Wr., Ocr. I7, 1970, at I24-3r.
} 
ever challenging process of monitoring current behavioral patterns while simultaneously attempting to forecast future demand.

Apart from this dynamic environment there is what Michael Harrington has called the "Other America."11 Although not restricted to the depressed ghettos of our major cities, poverty is increasingly becoming an urban problem. Many of the poor living in these congested areas are black and suffer from racial discrimination as well as economic deprivation. Large numbers of these same poor are members of families that moved from the rural south to more northern cities where jobs appeared plentiful and public assistance was better. ${ }^{12}$

As a group they were studied intensely during the I 960 's and, therefore, identified and classified, although not necessarily fully understood. In this process the poor in the United States have been characterized in economic terms by dollar thresholds to poverty. By recent standards, a nonfarm household of four would be considered poor if their combined annual income were $\$ 3553$ or less, while a two member household would not be classified as poor if their income exceeded $\$ 2262 .{ }^{13}$ Nevertheless, poverty is much more than this, as the Mayor's Commission of Cleveland indicated. "It is attempting to sell blood to buy a child toys at Christmas and being turned away for being anemic. It is a child wearing $\$ \mathrm{r} .00$ tennis shoes through the winter. It is selling food stamps to buy sanitary napkins and toothpaste. It is covering one's mouth to hide missing teeth."14 To a large extent, this represents the populace of the areas where CDC's are located and, therefore, their most immediate market.

However, despite their sharing a common experience of economic deprivation, the poor are not a homogeneous group..$^{15}$ Therefore, the constituency of one CDC may well vary from that of another serving a different area. Or one CDC may itself be dealing with several identifiable groups. For example, even though poverty is fast becoming an urban problem with twenty-five per cent of all poor white persons and forty-two per cent of all poor black persons in this country residing within the central cities of our metropolitan areas, nearly half of all poor persons still live outside urban areas. ${ }^{10}$ The variation in congestion alone may dictate a different business mix for the $\mathrm{CDC}$ in a rural setting as compared to its counterpart servicing an urban environment.

Despite these and other dimensions of deprivation which demonstrate something less than perfect uniformity within the ranks of the CDC constituency, there are identifiable similarities. And after a cautious warning about too much generalization

\footnotetext{
${ }^{11}$ M. Harrington, The Other America: Poverty in the United States i-7 (Ig62).

12 Daniel P. Moynihan, Poverty in Cities, in The Metropolitan Enigma: Ineuines into the Natura and Dimensions of America's Urban CRIsis 337-39 (James Q. Wilson ed. r968).

${ }^{18}$ Bureau of the Census, Current Population Reports: Consumer Income, Poverty in the United StATES II (Ig69).

16 The Crists in Welfare in Cleveland: Report of the Mayor's Commission 3 (H. Stcin ed. 1969).

${ }^{16}$ Committee for Economic Development, Supplensentary Paper Number 26, A. Downs, Who Are The Urban Poor? i6-i7 (Ig68).

${ }^{10}$ Bureau of THE Census, supra note 13 , at 7 .
} 
regarding likenesses among the poor, the emphasis must be placed upon several clusters of similarities which can be used to help most CDC's develop market strategies for servicing the local residents. What follows is an attempt to identify some of the characteristics that people of the low-income areas typically served by CDC's have in common. Included here is an indication of what marketing implications these similarities offer. This represents a strategy of identifying the local constituency through the use of secondary sources of marketing information. Also, it suggests that CDC's need not have marketing research experts at their disposal, but that considerable data is already available with respect to their most immediate market.

\section{B. Predominant Life Styles of Neighborhood Residents and Their Marketing Implications}

The day-to-day behavioral patterns of the lower socioeconomic class which makes up most of the CDC's local market can be characterized by several distinctive themes, all of which are apparently related to a deprived, alienated position in society. The more salient themes include that of fatalism, an orientation to the present, authoritarianism, and concreteness. ${ }^{17}$ To a large extent the market behavior of the local residents, including their general receptiveness to CDC-run businesses, will be shaped by these themes.

This behavioral field is substantially different from that of the more general consumer population and, therefore, varied marketing techniques may be required if the low-income consumer is to be served effectively. For example, the fatalism of the poor appears to be a result of a genuine powerlessness they experience with respect to so much of their life. They feel controlled by external forces rather than being in control themselves. This attitude acts as a definitive brake on occupational and educational aspirations. It also retards their interest in such critical problems as health care. In addition, it may nurture a tendency to limit one's shopping scope or willingness to negotiate favorable terms when making a purchase. When either of these latter propositions is true, established local business has a distinct advantage in gaining consumer patronage, a competitive market advantage which the community-based enterprise must recognize. However, it is possible that the unique nature of the $\mathrm{CDC}$ as a broadly based community-owned entity, once understood by the constituency, will alleviate some of the feeling of complete helplessness. If so, this could represent a major contribution to facilitating a significant change in the attitude of the poor. And furthermore, it may enhance the possibility of realizing a successful relationship between $\mathrm{CDC}$-operated businesses and their local market.

An orientation toward the present goes hand in hand with fatalism. The poor generally feel that it is fruitless to anticipate the future, when fortune and chance

\footnotetext{
${ }^{17}$ Irelan and Besner, Low-Income Outlook on Life, in Low-Income Life StyLes 7-9 (L. Irelan ed. 1968).
} 
are considered its basic determinants. Also, when so much of one's personal resources must be expended simply to survive in the present, there is little time left to consider the future. This predisposition precipitates a lack of interest in planning for future needs and a general feeling of insecurity. As a result, a family frequently lives from one crisis to another.

This behavioral pattern can have various marketing implications for the community-based enterprise. For example, major durables may well be purchased on the basis of a short search experience following the realization of a need-possibly one resulting from the breakdown of an automobile or refrigerator. The need to replace such an item within a short period of time, coupled with other constraints on search behavior, will frequently lead the low-income shopper to go no further than his neighborhood dealer. Having an appropriate CDC-run business readily accessible within the immediate area will greatly enhance the probability of gaining local patronage.

This is not to suggest, however, that the poor are confined to the immediate neighborhood for their shopping. Many go outside to make selected purchases and, therefore, the community-based enterprise must view its competitors as including most of the major retail outlets in the surrounding area. ${ }^{18}$ This will at least require merchandising policies that offer benefits to the local residents similar to those available at alternative retail outlets. Particular attention should be directed to customer servicing policy. Evidence from several studies shows that variation in personal aspects of customer servicing are particularly important in gaining the patronage of the low-income consumer. For example, both Caplovitz and Rainwater discovered a discomfort in working class women shopping in downtown stores, apparently a result of a lack of empathy among clerks toward the problems of the less affluent. ${ }^{10}$

A third theme by which the poor live is that of authoritarianism. Generally, this is a belief in strength as the source of authority and in the rightness of existing systems. This perspective arises in part from the limiting, mundane life experiences to which those living in poverty have become accustomed and also from the constant subordination of the poor to the rest of society.

Such a predisposition has particular marketing implications. First, it is likely to reduce one's interest in aggressive shopping. A role of subordination to the local merchant may be accepted as a continuation of a more general subordination in society. In order to combat such ready acceptance of merchant domination in the customer-dealer relationship, the community-based enterprise must promote the utilization of collective action as a means for equalizing bargaining strength. In addition, CDC businesses may offer an equitable relationship between buyer and seller. This will of necessity have to include flexible credit terms to meet both the special needs of the local residents and the competition from the merchants who

\footnotetext{
${ }^{18}$ D. Caplovitz, The Poor Pay More 54-57 (1967).

${ }^{10}$ L. Rainwater, R. Coleman, and G. HaNdel, Workingman's Wife 182-89 (r959).
} 
remain in the area or who selectively solicit the residents' business through their door-to-door representatives.

The availability of favorable credit terms is generally a critical consideration to local consumers when buying appliances and home furnishings. ${ }^{20}$ In fact, the principal competitive advantage may well accrue to the merchant who can offer "easy" credit. As a result, low-income market retailers frequently specialize in granting credit to consumers who may not have any credit references or who may have a poor credit rating by normal standards. The CDC will also have to deal with another phase of the local merchant's credit business. It is the practice of encouraging customers to make weekly payments in person, which further exposes them to the enticing wares of the merchant. Upon an expression of interest in new merchandise, the local retailer frequently responds with a willingness to provide the consumers with the desired goods at no increase in weekly payments, thereby further extending the number of visits the residents must make to the established store. ${ }^{21}$

A final life theme of the poor is that of concreteness. It reflects a life-pattern of placing greater emphasis on material goods than intellectual things. It has evolved quite logically among a group of people preoccupied by material problemssuch as keeping a roof over their heads and food on the table. Concreteness becomes evident in verbal patterns, in the distrust of intellectualism, and in occupational values. As a result, the life of the poor includes fewer generalizations, relies less on the conceptual process than on observation, and is more tied to the world of immediate happenings and momentary sensations. In a purchase experience, such an orientation may lead to placing most importance on the breadth of product features, convenience of operation, and brand name, rather than on more long-run considerations including durability, economy of use, and frequency of repair. ${ }^{22}$ Here again, strong overt effort will be necessary on the part of the CDC to overcome the consequences of a predisposition toward concreteness. Nevertheless, if the local consumer can be reached through advertising and direct contact with the $C D C$ businesses and is made to realize the benefits of altering his previous behavioral tendencies, much greater consumer satisfaction should result. And of equal importance, customer loyalty to the community-based enterprise should be enhanced.

\section{Marketing Information and the Poor}

So far emphasis has been placed upon understanding the fundamental nature of the low-income consumer's predispositions toward life and in interpreting these in a marketing context. However, once these behavioral tendencies are identified and

\footnotetext{
${ }^{20}$ In Washington, D.C., the Federal Trade Commission found that as a group, low-income market retailers who sell durables made $93 \%$ of their sales through installment credit. Federal Trade Commission, Economic Report on Installment Credit and Retail Sales Practices of District of Columbia Retailers, in The Ghetto Marketplace, 8I (F. Sturdivant ed. I969).

${ }^{21}$ Huber, The Poor in the Market Place, in Power, Poverty ANd URBan Policy, 167-68 (W. Bloomberg, Jr. and H. Schmandt eds. I968).

${ }^{22}$ Richards, Consumer Practices of the Poor, in Low-Income Life StyLEs, supra note 17, at 75.
} 
the product and service mix of the businesses properly adjusted so as to take maximum advantage of this insight, attention must be given to the subject of communication. The objective of this communication should be to foster an effective flow of pertinent consumption facilitating information from the business source to the low-income consumer user.

One recent study showed that when given sufficient time to deliberate the problem of making a major purchase, the poor respond similarly to our model of economic man in search of product information. There is a recognition of the need for product information generally considered most relevant, even though in an actual buying situation the poor may not make an exhaustive search for such information. ${ }^{23}$ A sample group of low-income consumers was asked to identify the type of information which should be secured before a large purchase is made. Three times as many respondents requested product-oriented information as desired dealer-oriented data. This latter finding may in part reflect the limited flexibility that the poor have with respect to dealer choice. Such constraints on their shopping scope are exemplified by the fact that only twenty-three per cent of the $35^{\circ}$ households studied had access to an automobile and forty-two per cent stated they were limited to shopping within walking distance of their home.

Given the general plight of the poor, a very basic question concerning the availability of consumption facilitating information might be raised: Are these people as deprived of information dealing with the selection of goods and services as they are of the goods and services themselves? There is evidence to indicate that the mass media do reach the urban poor in significant numbers. Furthermore, television and newspapers appear to be the two most effective modes of communication for reaching the poor. In fact, over seventy per cent of the St. Louis respondents were found to be regular television viewers and approximately two-thirds of the interviewees read or at least looked at a newpaper almost everyday. ${ }^{24}$

Newspapers and television were also found to be the two most useful sources in helping these individuals choose a product, that is, help them to obtain the most for their money. Although personal contact may appear to be a very desirable means of communicating with economically deprived consumers, they themselves do not place as high a value on this type of exchange as one might expect. Also, they do not place as much emphasis on personal sources as do more affluent consumers interested in making similar purchases. ${ }^{25}$ The poor of the ghetto areas of St. Louis consider newpapers the best single source of product information with television the next best source. Advice from friends followed television as a source of product

\footnotetext{
${ }^{28}$ C. Block, Prepurchase Search Behavior of Low-Income Households, Nov. 12, 1970 (a paper pre- sented to the Southern Marketing Association Meeting, Atlanta, Ga.). This paper reports the findings of a study of the general prepurchase search behavior of 350 low-income households living in St. Louis in August, 1968.

${ }^{24}$ Block, Communicating with the Urban Poor: An Exploratory Inquiry, 47 JournaLISM Q. 4-9 (1970).

${ }_{25}$ Udell, Prepurchase Behavior of Buyers of Small Electrical Appliances, 30 J. Marketivo 51 (1966).
} 
information, while radio was ranked fourth, store window signs fifth, advice from sales clerks sixth, magazines seventh. Advice from social workers was considered the least desirable source of product information. ${ }^{26}$

Given the evidence, community-based businesses will probably find it impossible to depend upon personal word-of-mouth informational flow to communicate the virtues of their product and service offerings. In fact, it may be imperative that persuasive promotional messages be carried to the neighborhood constituency through the local media. In additon, some may find other techniques helpful as did the St. Louis grocery merchants serving the depressed areas. They found that mass media promotional efforts could be effectively supplemented by using home delivered advertisements-some of which were simply hand-printed memos promoting weekly specials.

\section{Selected Demographic Dimensions of the CDC Constituency and Their Marketing Implications}

Poor families tend to be larger than non-poor families. For instance, about five per cent of the families above the poverty line have seven members or more, while nearly sixteen per cent of all poor families have seven or more members. ${ }^{27}$ This attribute has a number of specific marketing implications. The desire for laborsaving durable goods is particularly strong among the poor, and this group is no less vulnerable than others to promotional messages emphasizing the features of these products. A serious consequence of this interest in labor-saving durables is that the high unit cost of any such purchase has a significant impact on an already overburdened budget. Given this evidence, it would seem desirable for some CDC's to develop a business service line responsive to the need for reducing the investment of family labor in tasks such as washing clothes. A chain of selfservice laundries might be the type of investment that would satisfy this particular need while at the same time operating as a profitable enterprise. Assuming that an appropriate business venture could be initiated, another social benefit would be realized; a substantial decline in the need for consumer durables among the poor would reduce one of the major sources of consumer exploitation in depressed areas. ${ }^{28}$

Age distribution is another important dimension of the constituency of CDC's. Among the poor, there is a large concentration of persons under 25 years old, many of whom are dependent children, and an equally important concentration of senior citizens. $^{29}$ It is not unusual to find large numbers of persons in this latter group who did not experience poverty until retirement. ${ }^{30}$

This bimodal age distribution suggests the existence of special needs. These include the need for a multitude of health-related products and services. One business

\footnotetext{
so Block, stpra note 24 , at 7 .

${ }^{27}$ Bureau of the Census, supra note 13 , at 4 .

${ }^{28}$ Federal Trade Commission, supra note 20 , at $8 \mathrm{r}-84$.

${ }^{20}$ Orshansky, The Shape of Poverty in 1966, 3I Soc. SEc. Bull. I6-I8 (Ig68).

${ }^{80}$ H. Brotman, A Profile of the Older American I-I5 (Ig68).
} 
investment that could facilitate the satisfying of these needs, while still presenting a viable business venture, is the discount drug outlet. Another is an establishment supplying various equipment for the ill or injured on a rental basis.

Provision for service to older neighborhood residents must be structured to reflect other features. Not only are some of the elderly experiencing poverty for the first time, but their plight seems even more permanent than that of others. These aging persons recognize that they have passed the time when they were active participants in their community and that they are in a period of decline that may ultimately end in complete dependency. Furthermore, like most low-income groups, the aging spend proportionately more of their income on food, shelter, fuel, and medical care than the average American. ${ }^{31}$ Consequently, the senior citizen is best served by a marketing strategy that stresses convenience of access with respect to sources of goods and services and which provides economy in a setting which preserves the dignity of the consumer.

\section{III}

\section{The Market Beyond the Immediate Neighborhood}

If the community development corporation extends its operations to markets outside the economically depressed area, it must confront the issue of its relative competitive position. There are two general alternatives to the issue. First, the CDC can enter competition through the marshalling of its own resources or through the acquisition of a firm already established in the selected field. In either case, the $\mathrm{CDC}$ is likely to face competition from other established competitors and from potential competitors, if the market or product involved is lucrative. Under this strategy, the CDC does not have any real differential advantage available to it that is not also available to any other competitor within the framework of a capitalistic structure. The second alternative for the CDC is entry into selected areas where some differential advantage might exist, either through artificial or natural market forces. The discussion here will concentrate on the later approach since it is likely to be the more promising.

\section{A. The Governmental Market}

The federal procurement program contains several provisions highly favorable for any firm, controlled or owned by minority persons or located in a labor surplus area, which desires to serve the government market. The Small Business Administration was authorized by the Small Business Act to negotiate with other federal agencies and departments the conditions under which certain procurement needs for property, services, maintenance, repair, construction and research and development are set aside, either totally or partially, and bidding is restricted to small businesses. ${ }^{32}$

\footnotetext{
${ }^{81} 7 d$.

${ }^{32}$ For definitions of small business concerns, see Federal Procurement Regulations, Subpart $x-x . y 0 r$. In general, it can be assumed that all $\mathrm{CDC}$ 's are small businesses at this time.
} 
In the case in which bidding for an individual item or an entire class of items is totally restricted to small business concerns, the CDC firm would be bidding against other established small businesses. Since the definition of a small business is rather liberal (e.g., in manufacturing the maximum employee limitations range from $75^{\circ-1500}$ ), the $\mathrm{CDC}$ would probably meet some vigorous competition. Where only a portion of an individual item or a class of items is set aside, the CDC firm does have some advantage, in that the highest priority is given to firms located in sections of concentrated unemployment. However, that advantage is offset by two factors: the unit price contracted on the unexempted portion of the procurement agreement is the ceiling on the set-aside portion and preferential treatment for labor-surplus area concerns are disallowed in defense procurements. From I96I through 1967, federal procurement set-asides for small business ranged from 4 to 6.3 per cent of total federal procurements, with the greatest absolute amount being $\$ \mathrm{r} .9$ billion in $1967 .^{33}$

Of greater benefit to the $C D C$ is the provision under section 8(a) of the Small Business Act which authorizes the Small Business Administration to provide assistance, through a subcontracting program, to small business concerns owned and operated by economically or socially disadvantaged persons. Through cooperation between SBA and government procurement agencies, the SBA acts as prime contractor for specific items and subcontracts to one or more minority-owned small businesses. The section 8 (a) program was first begun in late $196 \%$, with the SBA subcontracting about $\$ 50$ million by early 1970 in more than eighty subcontracts. $^{34}$ The SBA had set a goal of \$100 million in commitments through the section 8(a) program by July, 197I, and it appears that this goal will be reached and perhaps slightly exceeded. ${ }^{35}$ The section $8(a)$ program does have some serious weaknesses, however, which might make the market less attractive to the CDC than other alternatives. First, the SBA, as late as April, I969, had only five people working directly on this program, with no apparent plans to add more. ${ }^{36}$ Considering the amount of coordination and administration inherent in these subcontracts, there would seem to be a practical limitation of $\$ 25-\$ 30$ million per year for all minority small businesses. Another important drawback is the fact that most of the subcontracts have been for defense procurements, including such products as tents, wooden pallets, wooden and metal boxes, bakery products, and military clothing, and such services as repair or modification of electronic equipment

\footnotetext{
${ }^{33}$ Hearings on the Position of Small Business in Government Procurement Before Subcomm. No. 2 on Gov't. Procurement and Economic Concentration of the House Select Comm. on Small Business, goth Cong., Ist Sess. 23 (I968).

84 1968 SBA ANN. Rep. 25-26; I969 SBA ANN. Rep. 23; Office of MiNoRity Business ENTERPRise, Bullding MinoRITY ENTERPRISE 23 (1970).

${ }^{\mathrm{as}}$ Hearings on Federal Minority Enterprise Program Before the Subcomm. on Small Business of the Senate Comm. on Banking and Currency, grst Cong., Ist Sess. 6 (1970).

${ }^{30}$ Hearings on the Department of State, Justice, and Commerce, The Judiciary, and Related Agencies' Appropriations for 1970 Before a Subcomm. of the House Comm. on Appropriations, 9Ist Cong., Ist Sess. 327 (1969).
} 
and modification of $\mathrm{T}_{-33}$ airctaft. ${ }^{37} \mathrm{~A}$ market of this nature is vulnerable to such things as a "reordering of priorities."

A preferential procurement policy for municipalities and state governments would open similar opportunities. While none exist at present, the Ghediplan, or Ghetto Economic Development and Industrialization Plan, as formulated by Dr. Dunbar S. McLaurin might serve as a basis for future action. ${ }^{38}$ Basically, the Ghediplan calls for New York City to set aside ten per cent of its "other than personal services" procurements in a manner similar to the section 8(a) federal program. According to Dr. McLaurin, New York City alone could provide a $\$ 50$ million "guaranteed market" for minority firms in its own depressed areas. ${ }^{30}$ A local government program such as this would probably be more effective and of more value to a CDC for several reasons. First, the $\mathrm{CDC}$ would be in a much more effective bargaining position in dealing with a municipal government rather than with a federal agency. Second, the general confinement of the geographical market would ease communications and aid coordination of some of the functional aspects of the community enterpirse. Third, the market would be non-defense oriented and thus could better prepare a new firm for entering the regular marketplace. Fourth, and possibly most important, the municipal government should be more sensitive to a CDC's needs than a federal agency could be.

\section{B. The Private Business Market}

Should the CDC find that government contracting is either undesirable or unavailable in a sheltered form for the product or service it has decided to furnish, a viable alternative is to seek sheltered markets through private corporations. While numerous community-owned enterprises have been started on the basis of a procurement commitment from a large corporation, it is difficult to determine the exact extent to which these commitments have sheltered the infant firm. In a few cases, the procuring firm has admittedly paid a premium-in effect a subsidy-for goods or services readily available from other sources. Procurement commitments have been made for as long as three years. These long-term commitments often serve as the basis for stimulating financing not otherwise available. Occasionally, the procuring firm will provide management support and services to assist the minority* owned firm in fulfilling the contract. In most cases of sheltered corporate markets, the sheltering corporation is accepting a risk in dealing with an unstable firm, which would probably not be undertaken using conventional economic criteria. Zion Investment Associates, Inc., has used sheltered markets to start two of its relatively successful ventures. ${ }^{40}$ In 1968, General Electric gave Zion's Progress Aero-

\footnotetext{
${ }^{87}$ I968 SBA ANN. ReP. 26; 1969 SBA ANN. Rep. 23.

${ }^{38}$ Hearings on Economic Development Opportunity Before the Senate Select Comm. on Small Business, goth Cong., 2d Sess. 233-475 (1968).

${ }^{39} I d$.

${ }^{40}$ Note, Community Development Corporations: Operations and Financing, 83 Harv. L. REv. 1558, $1563-65$ (1970).
} 
space Industries, Inc., a \$2.5 million order extending over an eighteen month period, in addition to planning and management assistance in starting the venture. When Zion later decided to form a venture for garment manufacturing, called Progress Garment Manufacturing Enterprises, the Villager Corporation gave purchase contracts and management assistance. Renmuth, Inc, a Detroit metal stamping operation started in part by catalytic action of the Inner City Business Improvement Forum, was headed by two former Ford employees and began operations with a three year purchasing commitment from Ford. ${ }^{41}$ The total cost of procuring some twenty-one parts from Renmuth will reportedly cost Ford several hundred thousand dollars more than if Ford continued making the parts, as it had in the past. There are other publicized corporation shelters. Xerox guaranteed $\$ 500,000$ in purchases for two years to Fighton, a new manufacturer of metal stampings and small transformers located in Rochester. Eastman Kodak helped set up Camura, a camera repair shop, and became its first customer. Eastman also gave P.A. Plastics, Inc., its plastic mold shop and a $\$ 150,000$ contract. S.S. Kresge retained a black-owned insurance company to underwrite group life insurance for over half its employees. ${ }^{42}$

Minority groups, including community development corporations, can sometimes use economic and social leverage to bring about sheltered markets. After sixteen weeks of boycotting and picketing, Operation Breadbasket in Chicago forced an agreement with A\&P to market minority produced products. ${ }^{43}$ Within six months after the agreement was reached, A\&P was marketing the products of twenty-five minority manufactures in its stores located in minority populated areas. As market strength is developed by the individual manufacturers, their products will be distributed by all 260 A\&P stores in the Chicago area. Several are now in this stage. One of these, Argia B's Food Products, has grown to a sales volume in six figures and now has a $10 \%-15 \%$ market penetration in the Chicago area for its one product, barbeque sauce. ${ }^{44}$ Since Operation Breadbasket made its original agreement with A\&P, a total of eight food store chains in the Chicago area have made similar arrangements. Whether Operation Breadbasket is a case of a forced shelter or simply the opening of a competitive market which was otherwise closed to minority manufacturers is open to speculation.

Private sheltered markets offer several advantages to a CDC. First, corporations generally have more flexibility than governmental agencies. Second, the private sector seems to offer a much broader market for possible products as compared to the federal procurement program which appears to be limited primarily to nonessential defense goods. The level of technology which an infant CDC operation can achieve may be relatively high, primarily because of the procuring firm's commitment to accept a risk and its ability to provide the new firm with managerial

\footnotetext{
${ }^{4}$ Scott, supra note 2, at 72.

${ }^{43}$ Brower and Little, White Help for Black Business, 48 Harv. Bus. Rev. 6 (I970).

${ }^{48}$ Berkner, Black Capitaitsm and the Urban Negro i8-ig (x970).

“ McKersie, Vitalize Black Enterprise, 46 Harv. Bus. Rev. 92 (Ig68).
} 
and technical assistance in an effective manner. There are risks for the CDC, however. It is possible that a corporation would be willing to provide a sheltered market because that product was unprofitable, or to put itself in a better negotiating position with other suppliers of the same product. Also the new firm may become dominated by the procuring firm and end up as a "captive" operation, but since many new enterprises start under similar conditions, this would not be a problem unique to a community-controlled firm. Probably the greatest shortcoming from the CDC's point of view is the conflict which might arise within the supporting corporation between socially oriented goals and traditional capitalistic goals.

Another alternative available to the community development corporation seeking some form of market shelter is franchising. If the franchisor has an effective marketing program, both locally and nation-wide, and grants an exclusive area franchise, the franchise holder has in effect a quasi-monopoly of a localized nature. Hough Area Development Corporation has operated a McDonald's Restaurant unit for some time and the Conservative Vice Lords in Chicago hold a Tastee Freeze franchise. 45

In recognition of the potential in franchising for the minority entrepreneur, the Small Business Administration and Office of Minority Business Enterprise have jointly instituted a program designed to increase the availability of franchise opportunities. Franchisors are invited to Washington in groups of twenty-five, where they are solicited to provide at least twenty-five new franchise opportunities to minority entrepreneurs over a two year period and to modify equity requirements consistent with the financial status of minority entrepreneurs. ${ }^{40}$ Upon enrollment the franchisor is screened by the Small Business Administration to determine his capability to fulfill the agreement. If the franchisor is found to be eligible, the SBA makes a blanket loan guarantee on all loans by the franchisor to the minority entrepreneurs. By early I970, seventy-two franchisors were enrolled of which fifteen were auto-related, twenty-five were food-oriented, and the remaining thirty-two provided a variety of other services.

In a related move, the Department of Commerce got a pledge from eighteen oil companies to increase the proportion of minority-held service station franchises. ${ }^{47}$ Specifically, the Department of Commerce set a goal of a proportion of minorityheld franchises equal to the minority proportion of the population.

Franchising has some specific advantages to offer the minority businessman, including management training and consultation, financial assistance, national advertising, brand image, and the localized quasi-monopoly position referred to earlier. Unfortunately, where a CDC is involved, the disadvantages are major. First, the great majority of franchises are retailing or service oriented. The franchisor retains

\footnotetext{
${ }^{45}$ Note, Community Development Corporations: Operations and Financing, 83 HaRv. L. REv. x558, 1658 (I970).

10 OfFice of Minority Business ENTERPRise, supra note 34 , at 31 .

${ }^{47}$ Id., at 33 .
} 
a relatively high degree of control in the form of detailed operational restrictions, constant supervision, and the threat of termination of the franchise. Furthermore, the management training that is provided by the franchisor is mostly of a low level nature and often for the sole purpose of enabling the franchisee to carry out the franchisor's instructions and rules. Most franchisors will only deal on an individual basis, not with a corporation, particularly one with a social orientation such as the CDC. The most serious drawback is the fact that while the franchisee may have a quasi-monopoly, the franchisor has rather complete control over his franchisees. This power can be exerted in the form of continuing charges for advertising and consulting, and required use of franchisor-supplied goods or services.

Franchises differ, of course, and each must be judged on its individual merits. In general, however, it would appear that franchising is not a viable long-term strategy for a community development corporation to follow in its direct business ventures, either in serving the economically-depressed area or the broader consumer market. This does not mean, however, that franchises should be entirely overlooked by the CDC. Indeed, a franchise program might be the most effective manner in which a CDC can act as a catalyst in matching the franchise opportunity and the minority entrepreneur and assisting the entrepreneur in setting up his operation.

\section{CONCLUSION}

The business practices of CDC's have not typically resembled the market-oriented posture of the modern business firm. Probably of necessity, community-based organizations have placed most emphasis on financing their infant operations and on establishing the physical facilities for servicing the local residents. However, in order to realize the greatest possible impact on the economic conditions in the lowincome areas which they serve, CDC's must now become market-oriented entities. This is particularly important because their primary consumer market is made up of people who are more suspicious and less well informed than those who populate the more affluent consumer market existing outside economically depressed areas.

The low-income area resident is to a large extent a captive consumer in that his shopping is effectively restricted to his immediate neighborhood. $\mathrm{He}$ is, however, by no means a captive of the CDC business. While convenience of location is probably a necessary condition for gaining his patronage, it does not guarantee his support. In fact, it appears that without a forceful marketing effort, the community-based enterprise is likely to lose out to established businesses because these firms are familiar to the local residents and are likely to continue to be aggressive in attempting to maintain their market position.

The CDC cannot fail to consider the potentially profitable opportunities beyond the neighborhood economy, for these may provide the means of gaining the greatest economic advantage presently available. Special arrangements offering a quasimonopolistic position to the CDC seem to be the most viable ventures. These 
opportunities include the section 8(a) program of the Small Business Administration and the proposed program for developing a preferential procurement policy for state and local governments. Other opportunities exist in the private business market. Varying forms of preferential treatment have provided the major market impetus for several organizations. Also, CDC's might turn to franchising as means of gaining the desired quasi-monopoly market position. Each of these approaches, however, will involve the CDC with private or governmental institutions from outside the depressed area which it serves. While the economic benefits of such associations are attractive, the controls which these agencies impose may conflict with the social goals of the CDC. In its movement toward greater involvement in markets beyond the neighborhood, the CDC will likely be required to reassess the compatability of its social and economic goals. 